\title{
PENYAKIT SKABIES BERHUBUNGAN DENGAN PERSONAL HYGIENE MASYARAKAT
}

\author{
Elma Mentaya, Noraida, Abdul Khair \\ Poltekkes Kemenkes Banjarmasin Jurusan Kesehatan Lingkungan \\ Jl. H. Mistar Cokrokusumo No.1A Banjarbaru Kalimantan Selatan \\ E-mail: elmamedina8@gmail.com
}

\begin{abstract}
Scabies Disease Connected With Personal Hygiene Communities. Based on the Hulu Sungai Tengah District Health Office report, scabies continues to exist and is a problem that must to resolved immediately. The working area of the Pagat Health Center, which is one of the sub-districts in Hulu Sungai Tengah, experienced the highest increase in scabies cases. The purpose of this study was to determine personal hygiene relations include bathing habits and habit of using soap together with scabies in the working area of the Pagat Health Center. This type of research uses a retrospective approach (case-control study), which compares the behaviour of the sick group with a lively group associated with the incidence of scabies. The sample of this research is 30 people. Data will be analyzed using the $x^{2}$ test (Chi-square). The results of this study indicate there is a relationship between bathing habits with the incidence of scabies $P$-value $=0.026<\alpha=0.05$, there is a relationship between the use of soap with the prevalence of scabies $P$-value $=0.024<\alpha=0.05$. Suggestions such as providing health education with excellent and correct bathing methods, using liquid soap or antiseptic soap.
\end{abstract}

Keywords: Personal Hygiene; Scabies

\begin{abstract}
Abstrak: Penyakit Skabies Berhubungan Dengan Personal Hygiene Masyarakat. Berdasarkan laporan Dinas Kesehatan Kabupaten Hulu Sungai Tengah menunjukan penyakit skabies terus menerus ada, dan merupakan masalah yang harus segera diselesaikan, wilayah kerja Puskesmas Pagat yang merupakan salah satu kecamatan yang ada di Hulu Sungai Tengah mengalami peningkatan tertinggi kasus skabies, Tujuan penelitian ini adalah untuk mengetahui hubungan personal hygiene masyarakat meliputi kebiasaan mandi dan kebiasaan menggunakan sabun bersamaan dengan kejadian skabies di wilayah Kerja Puskesmas Pagat. Jenis penelitian ini menggunakan pendekatan restropektif (case control study), yaitu membandingkan perilaku antara kelompok sakit dengan kelompok sehat yang berhubungan dengan kejadian skabies. Sampel penelitian ini berjumlah 30 orang. Data akan dianalisis menggunakan uji $x^{2}$ (Chi square). Hasil penelitian ini menunjukan ada hubungan kebiasaan mandi dengan kejadian skabies $P$-value $=0,026<\alpha=0,05$, ada hubungan penggunaan sabun dengan kejadian skabies $P$-value $=0,024<\alpha=0,05$. Saran yang diberikan seperti memberikan penyuluhan kesehatan dengan materi cara mandi yang baik dan benar, menggunakan sabun cair atau sabun anti septik.
\end{abstract}

\section{Kata Kunci: Kebersihan Perorangan; Skabies}

\section{PENDAHULUAN}

Penyakit kulit merupakan salah satu penyakit yang menjadi masalah kesehatan nomer 2 di Indonesia. Menurut Direktorat Jendral Pelayanan Medik Departemen Kesehatan Republik Indonesia tahun 2006 penyakit kulit dan jaringan subkutan berdasarkan pravalensi 10 penyakit terbanyak pada masyarakat Indonesia menduduki peringkat ke 2 setelah infeksi saluran pernafasan akut dengan jumlah 501.280 kasus atau 3,16 \%. Penyakit kulit bisa menyerang siapa saja, dari kalangan atas sampai kalangan bawah. Kulit merupakan organ terbesar pada tubuh manusia yang membungkus otot-otot dan organ-organ dalam serta merupakan jalinan jaringan pembuluh darah, saraf, dan kelenjar yang tidak berujung, semuanya memiliki potensi untuk terserang penyakit yang salah satunya adalah penyakit kulit[1]. Dikarenakan Indonesia memiliki kawsan yang padat penduduk dengan sanitasi yang tergolong buruk. Dan salah satu provensi di Indonesia yaitu Kalimantan selatan masih terdapat penyakit skabies di salah satu 
kabupaten yaitu kabupaten hulu sungai tengah masih di temukan penyakit skabies selama 3 tahun terakhir.

Berdasarkan dari laporan Dinas Kesehatan Kabupaten Hulu Sungai Tengah menunjukan penyakit skabies terus menerus ada, dan ini merupakan masalah yang harus ditanggulangi. Kejadian kasus penyakit skabies pada tahun 2015 terdapat 93 kasus, tahun 2016 terdapat 167 kasus dan pada tahun 2017 terdapat 151 kasus di seluruh wilayah kerja Dinas Kesehatan Kabupaten Hulu Sungai Tengah. Wilayah kerja Puskesmas Pagat yang merupakan salah satu kecamatan yang ada di Hulu Sungai Tengah mengalami peningkatan tertinggi[2]. Berdasarkan data dari angka kunjungan klinik sanitasi di Puskesmas Pagat pada tahun 2015 terdapat 1 kasus, 2016 terdapat 4 kasus, tahun 2017 terdapat 15 kasus, dan pada tahun 2018 terdapat 10 kasus yang terregister di Puskesmas Pagat berdasarkan data tersebut data kasus terjadi kenaikan. Salah satu penyebab terjadinya penyakit skabies yaitu personal hygiene atau sering disebut kebersihan perorangan.

Personal hygiene atau kebersihan diri adalah upaya seseorang dalam memelihara kebersihan dan bertujuan untuk mencegah timbulnya penyakit. Menjaga kebersihan bagian badan adalah hal yang harus di dilakukan oleh anak-anak maupun orang dewasa agar terhindar dari penyebaran penyakit. Personal hygiene mencakup beberapa hal seperti, perawatan kulit kepala dan rambut, mata, hidung, telinga, kuku tangan dan kaki, dan perawatan tubuh secara keseluruhan. Personal hygiene adalah aspek yang sangat penting dari pendidikan kesehatan[3]. Penularan penyakit skabies dapat melalui kontak tidak langsung seperti melalui perlengkapan tidur, pakaian, atau handuk memegang peranan yang penting ${ }^{[4]}$.

\section{BAHAN DAN CARA PENELITIAN}

Jenis penelitian ini bersifat analitik dan dilakukan secara observasional dan lembar kuesioner dengan rancangan case control merupakan rancangan penelitian yang membandingkan antara kelompok kasus dan control untuk mengetahui masyarakat yang menderita skabies dan tidak skabies di wilayah kerja puskesmas pagat yang personal hygiene yang baik dan yang buruk.

Populasi kasus dalam penelitian ini adalah seluruh penderita skabies yang teregister di puskesmas pagat yang berjumlah 10 responden dan populasi kontrol dalam penelitian ini yang tidak menderita skabies yang teregister di puskesmas pagat yang berjumlah 20 responden.

\section{HASIL PENELITIAN DAN PEMBAHASAN}

Penelitian ini dilaksanakan di salah satu desa yang berada di Kabupaten Hulu Sungai Tengah yang masuk di wilayah kerja Puskesmas Pagat yang secara geografis puskesmas terletak di Kecamatan Batu Benawa.

Tabel 1. Hubungan Kebiasaan Mandi Dengan Kejadian Skabies

\begin{tabular}{cccccc}
\hline \multirow{2}{*}{ Kebiasaan Mandi } & \multicolumn{5}{c}{ Skabies } \\
\cline { 2 - 5 } & Jumlah & Ya & Jumlah & $\%$ \\
Buruk & 5 & 50 & 2 & 10 \\
Baik & 5 & 50 & 18 & 90 \\
Total & 10 & 100 & 20 & 100 \\
& Sig $=0,026$ & \multicolumn{2}{c}{$\propto=0,05$} \\
\hline
\end{tabular}

Sumber:[5]

Hasil penelitian menunjukan bahwa kebiasaan mandi dengan kejadian skabies yang ya menderita skabies memiiki kebiasaan mandi yang sama sebanyak 5 orang (50\%) sedangkan yang tidak skabies memiliki kebiasaan mandi yang baik sebanyak 18 orang (90\%). Hasil 
data hubungan antara kebiasaan mandi

dengan kejadian skabies.

Tabel 2. Hubungan Kebiasaan Menggunakan Sabun Dengan Kejadian Skabies

\begin{tabular}{cccccc}
\hline & \multicolumn{5}{c}{ Skabies } \\
\cline { 2 - 6 } Kebiasaan Menggunakan Sabun & Ya & \multicolumn{3}{c}{ Tidak } \\
& Jumlah & $\%$ & Jumlah & $\%$ \\
Buruk & 1 & 10 & 11 & 55 \\
Baik & 9 & 90 & 9 & 45 \\
Total & 10 & 100 & 20 & 100 \\
& Sig=0,024 & & \multicolumn{2}{c}{$\propto=0,05$} \\
\hline
\end{tabular}

Sumber:[5]

Hasil penelitian menujukan bahwa kebiasaan menggunakan sabun dengan kejadian skabies yang ya skabies memiliki kebiasaan menggunakan sabun yang baik sebanyak 9 orang $(90 \%)$ sedangkan yang tidak skabies memiliki kebiasaan mandi yang buruk sebanyak 11 orang (55\%). Hasil data menunjukan hubungan kebiasaan menggunakan sabun dengan kejadian skabies

Menurut teori kebiasaan mandi berhubungan dengan kebersihan kulit maupun kebersihan rambut. Kebersihan kulit merupakan cerminan kebersihan yang pertama memberikan kesan. Oleh karena itu perlu memelihara kulit sebaikbaiknya. Dalam memelihara kebersihan kulit, kebiasaan-kebiasaan yang sehat harus selalu diperhatikan adalah kebiasaan mandi minimal 2 kali sehari, mandi memakai sabun, dan menjaga kebersihan lingkungan[6]. Hasil penelitian tersebut diketahui dari 10 responden di

\section{KESIMPULAN DAN SARAN}

Kebiasaan mandi masyarakat di wilayah kerja puskesmas pagat diketahui dari kelompok ya skabies memiliki kebiasaan mandi yang setara antara baik dan buruk sebanyak 5 orang (50\%). Sedangkan dari kelompok tidak skabies cenderung memiliki kebiasaan mandi yang baik sebanyak 18 orang (90\%). Ada hubungan antara kebiasaan mandi dengan kejadian skabies di wilayah kerja puskesmas pagat. Kebiasaan penggunaan sabun dengan kejadian masyarakat di wilayah kerja puskesmas pagat diketahui di kelompok ya skabies cenderung kelompok sakit cenderung memiliki kebiasaan mandi yang setara antara baik dan buruk sebanyak 5 orang (50\%). Sedangkan dari 20 responden di kelompok sehat cenderung memiliki kebiasaan mandi yang baik sebanyak 18 orang $(90 \%)$.

Menurut teori penggunaan sabun batang secara bersamaan akan menyebabkan mudahnya perpindahan kuman sehingga tidak baik untuk kesehatan kulit, sabun batang juga sangat mudah ditempeli kotoran dan kuman, serta kotoran dan kuman bisa mengendap pada sabun batang [6]. Hasil penelitian tersebut diketahui dari 10 responden di kelompok sakit cenderung memiliki kebiasan menggunakan sabun yang baik sebanyak 9 orang (90\%). Sedangkan dari 20 responden di kelompok sehat cenderung memiliki kebiasan menggunakan sabun yang buruk 11 orang $(55 \%)$.

memiliki kebiasan menggunakan sabun yang baik sebanyak 9 orang (90\%). Sedangkan dari kelompok sehat cenderung memiliki kebiasan menggunakan sabun yang buruk baik 11 orang (55\%). diharapkan masyarakat untuk Mengganti kebiasaan menggunkan sabun batang ke sabun cair atau sabun anti septik, melakukan dan membiasakan membesihkan seluruh anggota tubuh untuk peneliti selanjutnya disarankan untuk menambah responden dan memperluas cangkupan tentang personal hygiene. 


\section{KEPUSTAKAAN}

1. Candra TN, Permatasari E, Jember M, Fakultas D, Kesehatan I, Muhammadiyah U, et al. HUBUNGAN PERSONAL HYGIENE DENGAN KEJADIAN PENYAKIT KULIT PADA TUNA WISMA DI KECAMATAN JELBUK KABUPATEN JEMBER. 2015;

2. Dinas Kesehatan Kabupaten Hulu Sungai Tengah. Data Penyakit Seluhur Puskesmas Di Kebupaten Hulu Sungai Tengah. Barabai: Dinas Kesehatan KAbupaten Hulu Sungai Tengah; 2017.
3. Aulia FI. Pengaruh Pendidikan Kesehatan Tentang Personal Hygiene Terhadap Pengetahuan Dan Sikap Siswa Di SDN Rembes 1 Dusun Watugimbal Kecamatan Beringin Kabupaten Semarang. Surakarta: UNIVERSITAS MUHAMMADIYAH SURAKARTA; 2014.

4. Mansyur M, Wibowo AA, Maria A, Munandar A. Pendekatan Kedokteran Keluarga pada Penatalaksanaan Skabies Anak Usia Pra-Sekolah. 2015;57(February). 